DOI https://doi.org/10.36059/978-966-397-117-9/2-16

\title{
ADMINISTRATIVE JURISDICTION AND THE CODE OF ADMINISTRATIVE LEGAL PROCEEDINGS OF UKRAINE AS REVISED IN 2017: IS IT A NEW SOLUTION TO A PROBLEM OR THE OLD UNRESOLVED CHALLENGES?
}

\section{Bevzenko V. M.}

\section{INTRODUCTION}

Full exercise of the right to appeal against a court decision, actions or inaction of state authorities, local self-government bodies, officials and officers (Article 55 of the Constitution of Ukraine) ${ }^{1}$, the right to a fair justice $^{2}$ as well as successful protection of rights, freedoms, interests provide for the obligatory consideration of actual and normative preconditions. Such preconditions function as peculiar "filters", since they prevent the unreasonable justice, preventing the court from considering and resolving inappropriate or unjustified disputes.

Although these preconditions-filters have their own nature, content and peculiarities, all of them determine the prospective of appealing to the court as well as opportunity for further protection of rights, freedoms and interests. Absence or non-conformity of one of such preconditions will make the opening of proceeding in a legal case, satisfaction of claim requirements complicated or even impossible, as well as preventing from legal proceedings in general.

It is considered that the preconditions for the protection of rights, freedoms, and interests of administrative-legal relations in administrative procedure are as follows ${ }^{3}$.

1) The compliance of all actual circumstances of the administrativelegal dispute with the criteria of administrative jurisdiction;

\footnotetext{
1 2. Конституція України від 28 червня 1996 року // Відомості Верховної Ради України. - 1996. № 30. - Ст. 141 .

2 Конвенція про захист прав людини і основоположних свобод від 4 листопада 1950 року: ратифікована Законом України від 17 липня 1997 року № 475/97-ВР // Відомості Верховної Ради України. - 1997. - № 40. - Ст. 263.

Бевзенко В.М. Передумови захисту в адміністративному судочинстві прав, свобод, інтересів учасників публічно-правових відносин / В.М. Бевзенко // Сучасна адміністративно-правова доктрина захисту прав людини: тези доп. та наук. повідомл. учасн. наук.-практ. конф. (м. Харків, 17-18 квітня 2015 року). - Харків: Право, 2015. - С. 73-76.

4 Адміністративне судочинство України: теорія та практика: монографія / кол. авт.; за заг. ред. O.М. Нечитайла. - К.: ВАITE, 2015. - С. 173-174.
} 
2) The fact that the defendant violates the rights, freedoms, interests of the plaintiff;

3) The existence of the right of the subject to appeal to the court for appealing decisions, actions or inaction of state authorities, local selfgovernment bodies, officials and officers, or for fulfilling the duties of the subject of authority;

4) The plaintiff's right to claim;

5) The plaintiff is in administrative-legal relations with the subject of authority, which is determined as a defendant;

6) Compliance of the method of judicial protection proposed by the plaintiff in the statement of claim, with the methods of protection stipulated in the norms of the Code of Administrative Legal Proceedings of Ukraine (Article 5, 245 of the CAP of Ukraine of 2017), as well as compliance of the method of judicial protection with the actual disputed administrative-legal relations;

7) Compliance of administrative discretion with the administrative court discretion; the possibility of interference of this court in the discretion of participants of administrative-legal relations from which a conflict has arisen;

8) The availability of precedence practice of administrative-legal dispute resolutions by the Supreme Court, the European Court on Human Rights.

The presence of administrative jurisdiction (compliance of all actual circumstances of administrative-legal dispute to the administrative jurisdiction criteria) is among such preconditions which require proper description and justification. This institution of administrative procedural law, although provided by the Code of Administrative Legal Proceedings of Ukraine and of fundamental importance not only for the administrative procedure, but also for judicial system of Ukraine as a whole, still remains an institution which meaning is determined insufficiently. Clarification of the type of court jurisdiction, differentiation of administrative jurisdiction from other types of court jurisdiction is the challenge in relation to administrative courts and participants in administrative cases, their representatives, and participants in the administrative procedure which has been not overcome yet.

Studying the topic of administrative jurisdiction, one should take into account the fast development of existing and emergence of new, until 
recently unknown public relations as well as adoption of new legislation; one should expect the complexity of the court jurisdiction definition with the beginning of the procedural activity of the Supreme Court on intellectual property issues, etc. Therefore, there is an objective need not only to perceive these relations properly, but also to evaluate them, to make reasonable, legitimate conclusions based on unambiguous and clear criteria.

\section{The Analysis of the Latest Studies and Publications}

Determining a certain type of court jurisdiction, differentiating the administrative jurisdiction from other court jurisdictions is not an easy thing and it takes much time. Many legal scholars and lawyers-practitioners had to devote their research to this very issue. The essence and legitimacy of administrative jurisdiction, its limits and relations with other court jurisdictions was the research subject of V.V. Gordeeva, V.V. Ilkova, V. K. Kolpakov, R.O. Kuibida, O.M. Pasenyuk, V.G. Perepeliuk, M. I. Smokovich, V. S. Stefaniuk, M. I. Tsurkan 56789101112.

A lot of attention was paid to the content definition of administrative jurisdiction and its differentiation from other types of court jurisdiction (constitutional, criminal, economic, civil) by the Plenum of the Higher Administrative Court of Ukraine, in particular, in the resolutions "On certain issues of the administrative courts jurisdiction", "On the practice of application of legislation on access to public information by administrative courts"13 14 .

\footnotetext{
5 Колпаков В.К. Теорія і практика адміністративного судочинства: монографія / В.К. Колпаков, В.В. Гордєєв. - Чернівці: Місто, 2011. - 384 с.

${ }^{6}$ Ільков В.В. Правова природа справ адміністративної юрисдикції та її вплив на застосування джерел права в адміністративному судочинстві в Україні / В.В. Ільков // Наше право. - 2014. - № 5. - С. 60-70.

${ }^{7}$ Куйбіда Р. Межі адміністративної юрисдикції: спірні питання / Р. Куйбіда // Юридичний вісник України. - 2007. - № 25(625). - С. 6-7.

${ }^{8}$ Адміністративна юстиція України: проблеми теорії і практики. Настільна книга судді / за заг. ред. О.М. Пасенюка. - К.: Істина, 2007. - 608 с.

9 Перепелюк В.Г. Адміністративне судочинство: проблеми практики / В.Г. Перепелюк. - К.: КонусЮ, 2007. - 272 c.

10 Смокович М.I. Визначення юрисдикції адміністративних судів та розмежування судових юрисдикцій: монографія / М.I. Смокович. - К.: Юрінком Інтер, 2012. - 304 с.

${ }^{11}$ Стефанюк В.С. Судовий адміністративний процес: монографія / В.С. Стефанюк. - Харків: Фірма «Консум», 2003. - 464 с.

12 Цуркан M.І. Правове регулювання публічної служби в Україні. Особливості судового розгляду спорів: монографія / М.I. Цуркан. - Харків: Право, 2010. - 216 с.

Про окремі питання юрисдикції адміністративних судів: постанова Пленуму Вищого адміністративного суду України від 20 травня 2013 року № 8 [Електронний ресурс] - Режим доступу: http://zakon0.rada.gov.ua/laws/show/v0008760-13
} 
Thus, the Plenum of the Higher Administrative Court of Ukraine explained that when adopting the decisions on the norm reference to public law, and the dispute to public legal disputes, the courts should take into account general theoretical and legislative criteria, namely ${ }^{15}$ :

- The party to a public-legal dispute is an executive power body, a local self-government body, their official or officer or other subject exercising power management functions;

- The dispute is public-legal, belongs to the jurisdiction of administrative courts and complies with the definition of an administrative case specified in clause 1, part 1, Art. 3 of the CAP of Ukraine of 2005;

- The existence of managerial legal relations and legal relations related to the public formation of the power subject.

In order to ensure the uniform application of the legislation provisions on access to public information by administrative courts, the Plenum of the Higher Administrative Court of Ukraine interpreted the concept of "public information" and other types of information, it interpreted the relation between the categories of "public information administrator" and "subject of authority", and also spoke about the effect of norms of the Law of Ukraine "On access to public information"16 17.

As we can see, the criteria for administrative jurisdiction were borrowed from the articles of the Code of Administrative Legal Proceedings of Ukraine of 2005. So, part 1, Art. 2 of the Code states that the task of administrative legal proceedings is " ... the protection of rights, freedoms and interests of physical persons, rights and interests of legal entities in the field of public-legal relations from violations of ... public authorities, local self-government bodies, their officials and officers, other subjects in the exercise of their power management functions on the basis of legislation ...."

However, the criteria of administrative jurisdiction indicated in the above mentioned and other clarifications of the Higher Administrative

\footnotetext{
${ }^{14}$ Про практику застосування адміністративними судами законодавства про доступ до публічної інформації: постанова Пленуму Вищого адміністративного суду України від 29 вересня 2016 року № 10 [Електронний ресурс] - Режим доступу: http://zakon3.rada.gov.ua/laws/show/v0010760-16

15 Цуркан M.I. Правове регулювання публічної служби в Україні. Особливості судового розгляду спорів: монографія / М.І. Цуркан. - Харків: Право, 2010. - 216 с.

Про окремі питання юрисдикції адміністративних судів: постанова Пленуму Вищого адміністративного суду України від 20 травня 2013 року № 8 [Електронний ресурс] - Режим доступу: http://zakon0.rada.gov.ua/laws/show/v0008760-13

17 Про доступ до публічної інформації: Закон України від 13 січня 2011 року № 2939-VI // Відомості Верховної Ради України. - 2011. - № 32. - Ст. 314.

${ }_{18}^{18}$ Кодекс адміністративного судочинства України від 6 липня 2005 року № 2747-IV // Відомості Верховної Ради України. - 2005. - № 35-36, № 37. - Ст. 446.
} 
Court of Ukraine and the Supreme Court of Ukraine have not become indisputable means in overcoming the difficulties of determining the legal dispute type, unequivocal differentiation of administrative jurisdiction from other types of court jurisdiction. The legal disputes provoking discussions about their branch nature include, in particular, disputes involving the Public Council for Good Faith, the Deposit Guarantee Fund for Physical persons, and the Self-regulatory (organizations) professions authority (e. g., the Audit Chamber of Ukraine, Qualification-Disciplinary Commissions of Attorneys etc.), bodies of judicial self-government, etc.

Therefore, we must admit that legal community has not obtained yet the criteria for administrative jurisdiction definition, as well as the comprehensive grounds for reference of legal dispute to administrative court competence have not been justified.

\section{The Formation of Article Objectives}

It is obvious that, finally, the unified generally accepted criteria of the definition of certain public-legal dispute belonging to the administrative court jurisdiction must be developed to guarantee the full protection of rights, freedoms, and interests, the exercise of the right to fair trial, the provision of judicial practice unity, and the stability of court functioning of judicial system. In turn, the belonging (non-belonging) of a certain public-legal dispute to the administrative court jurisdiction, as well as the possibility of its differentiation from other types of court jurisdiction, should be judged by the total presence of external features of public-legal relations, from which the dispute arose. It is these features that could serve as criteria for administrative jurisdiction ${ }^{19} 202$. The absence of at least one of them will make impossible to refer a particular public-legal dispute to the administrative court jurisdiction.

Such criteria which total presence can help us to come to the conclusion about the existence of administrative jurisdiction are the following:

1) Administrative-legal relations;

2) The subject of authorities;

3) The administrative activity (carrying out administrative powers);

\footnotetext{
19 Бевзенко В.М. Адміністративна юрисдикція: поняття, сутність, проблеми відмежування / В.М. Бевзенко // Адміністративне право і процес. - 2013. - № 2(4). - С. 180-195.

${ }^{20}$ Бевзенко В.М. Новітнє адміністративне процесуальне право України: об'єктивна закономірність чи надумана вигадка? / В.М. Бевзенко // Форум права. - 2011. - № 1. - С. 68-73.

${ }^{21}$ Бевзенко В.М. Особливості визначення підвідомчості публічно-правових спорів / В.М. Бевзенко, С.М. Мінько // Вісник господарського судочинства. - 2007. - № 3. - С. 122-126.
} 
4) Administrative law norm;

5) The exercise of rights and observance of obligations in the field of public administration and/or rights and obligations, for violations or nonobservance of which may result in administrative consequences.

\section{The Basic Material of the Study}

In the Code of Administrative Legal Proceedings of Ukraine of 2005, the general criteria for determining the administrative jurisdiction, the scope and content of the competence of administrative courts were fixed. These criteria were peculiar markers, as their presence confirmed a public-legal dispute, which had to be considered and resolved by an administrative court. The conclusion on the normative consolidation of the administrative jurisdiction criteria in the Code of Administrative Legal Proceedings of Ukraine of 2005 can be made from the contents of Parts 1, 2 Art. 2, Art. 3, Art. 17, Art. 171-1837 , namely, the criteria based on the results after studying these norms, should be, in particular:

- Public-legal relations (part 1 Art. 2);

- State authorities, self-government bodies, their officials and officers, other subjects at carrying out power managerial functions, subjects of authorities (part 1 Art. 2, clause 7 part 1 Art. 3);

- Power managerial functions (part 1 Art. 2);

- Decisions, actions or inaction of the subjects of authorities (part 2, Art. 2);

- Administrative agreement, public service (clauses 14, 15 part 1 Art. 3 of the Code)

In addition to the criteria (criteria-markers), indicating the existence of administrative jurisdiction, in specific articles of the Code of Administrative Legal Proceedings of Ukraine in the revision of 2005, namely, in Art. 17, 171-1837, the list of public-legal disputes, subject to the jurisdiction of administrative courts, was directly consolidated.

However, the presence of both criteria-markers and the list of public legal disputes did not always allow answering the question unequivocally and in full: "Is there an administrative jurisdiction in a particular legal dispute?" Such complexity in the administrative jurisdiction definition can be explained, first of all, by the impossibility to formally describe one or another criterion clearly and in full as well as the category of public-legal dispute, to correctly correlate them with the actual circumstances of the case. It is obvious the these criteria and categories (types) of public-legal 
disputes have ambiguous evaluative legal nature, and thus, it is naturally that their perception and appropriate evaluation are carried out within the procedural discretion of administrative court, parties, third parties, and their representatives.

It is natural that the criteria evaluation of administrative jurisdiction at the discretion of the court determined the possibility of administrative courts to accept disputed decisions, even with regard to the same criteria of administrative jurisdiction or similar public-legal disputes.

In addition to the evaluative nature of the administrative jurisdiction criteria and public-legal disputes, their evaluation within the procedural discretion of the administrative court, the parties, third parties, their representatives, the impossibility of unambiguous description of these criteria and disputes is also resulted from their diverse scientific interpretations. In particular, modern science of administrative law has not yet developed a single and generally accepted understanding of the nature of all possible decisions, actions, inaction of the subjects of authorities, types of such subjects, the essence of public-legal relations, other criteria of administrative jurisdiction.

Finally, the conclusion on the administrative jurisdiction essence, its criteria and disputes that should be considered and resolved by administrative courts, taking into account the practice of functioning of the subjects of authorities (subjects of public administration) and the practice of administrative proceedings, must be substantiated by the science of administrative law and procedure. It is obvious that scientifically substantiated conclusions about the essence and criteria of administrative jurisdiction must unambiguously disclose the nature of this jurisdiction, while not depending on changes in legislation, reviewing of judicial practice, development and transformation of public relations.

In connection with the adoption and subsequent entry into force of the Code of Administrative Legal Proceedings of Ukraine of 2017, there were reasonable expectations that challenges (in particular relative to administrative jurisdiction) determined by the unequal implementation of administrative legal proceedings and other theoretical and applied peculiarities, finally, would have been successfully overcome. Therefore, it is time to ask a question: was experience of the Code of Administrative Legal Proceedings of Ukraine of 2005, taken into account in a new revision of the Code, and were unambiguous criteria for the determination of administrative jurisdiction introduced? 
We should focus on the description of articles of the Code of Administrative Legal Proceedings of Ukraine as revised in 2017 and try to find out if they managed to overcome the existing problems of administrative jurisdiction, and describe its criteria (administrative-legal relations, the subject of authority, administrative activity (the exercise of administrative powers), the norm of administrative law, exercise of rights and observance of obligations in the field of public administration or rights and obligations, for violation or non-compliance of which administrative legal consequences may occur).

First of all, it should be noted that in the Code of Administrative Legal Proceedings of Ukraine of 2017 the following procedural categories were equated such as "administrative jurisdiction" and "judicature of administrative cases". It is easy to make sure, if you draw attention to the fact that in Chapter 2 "Administrative jurisdiction" of Section I "General Provisions" of the Code of Administrative Legal Proceedings of Ukraine there are articles which provide for "administrative jurisdiction" (Art. 19), "instance jurisdiction" (Art. 22-24), "territorial jurisdiction (judicature)" (Art. 25-28). That is, the term "administrative jurisdiction" covers both administrative jurisdiction and judicature of administrative cases ${ }^{22}$.

Moreover, the Code has widened the nature of administrative jurisdiction: the content of administrative jurisdiction provides differentiation of public-legal disputes between local general courts and district administrative courts ("internal" administrative jurisdiction) (Art. 20) apart from the list of public-legal disputes which have to be considered and solved by administrative court as the holistic system ("external" administrative jurisdiction) (Art. 19).

At the same time with the updated presentation of the administrative jurisdiction essence in the Code of Administrative Legal Proceedings of Ukraine in the revision of 2017, new imperfect provisions complicating the application of its norms and, therefore, the implementation of administrative legal proceedings have appeared. In particular, in the case of non-compliance (violation) of rules on subject and instance jurisdiction (Art. 19, 20, 22-24 of the Code) it will be difficult to apply effective procedural instruments to overcome such non-compliance (violation).There is no specific legal norm authorizing to transfer administrative case in connection with the violation of rules on subject

\footnotetext{
${ }^{22}$ Кодекс адміністративного судочинства України від 6 липня 2005 року № 2747-IV; в редакції Закону України від 3 жовтня 2017 року № 2147-VIII // Відомості Верховної Ради України. - 2017. № $48 .-$ C. 5 .
} 
and instance jurisdiction (judicature) in the Code of Administrative Legal Proceedings of Ukraine in the revision of 2017.

It seems that it is possible to fill such legal gap by using the law analogy (Part 6, Art. 7 of the CAP of Ukraine in the revision of 2017) together with, in particular, Art. 29, 171 of the Code.

The courts of appeal and cassation have powers for the correction of consequences of incorrect determination of subject and instance administrative jurisdiction. Thus, according to the results of consideration on the court resolution appeal of the court of first instance, the court of appeal has the right to cancel the court resolution and refer the case for consideration to another court of first instance according to the established judicature (clause 5, part 1, Art. 315 of the CAP of Ukraine in the version of 2017). The court of cassation instance based on consequences of cassation appeal consideration has the right to cancel court resolutions of courts of the first and/or appellate instances in full or in part and to transfer the case in full or in part to a new consideration, in particular, in accordance with the established judicature or to continue the consideration (clause 2, part 1, Art. 349 of the CAP of Ukraine in the revision of $2017)^{23}$.

The analysis of norms of the Code of Administrative Legal Proceedings of Ukraine, as revised in 2017 (Art. 2, 19), proves that administrative-legal relations are still used as an administrative jurisdiction criterion. However, in the same way as in the Code of Administrative Legal Proceedings of Ukraine of 2005, such legal relations have still lacked a comprehensive description of their essence and principal features. Therefore, it seems obvious that the justification of legal relations will remain in the field of legal science (in particular, the science of administrative law and procedure), the conclusions of which should be properly examined by administrative proceedings practice.

The Code of Administrative Legal Proceedings of Ukraine stipulates the content of "a subject of authorities" concept in a comparatively wide way in the revision of 2017. Thus, the concept is supplemented by such subjects as attestation, competition, medical and social expert commissions and other similar authorities, which decisions are mandatory for state authorities, local self-government bodies, and other persons

\footnotetext{
${ }^{23}$ Кодекс адміністративного судочинства України від 6 липня 2005 року № 2747-IV; в редакції Закону України від 3 жовтня 2017 року № 2147-VIII // Відомості Верховної Ради України. - 2017. № 48. - C. 5 .
} 
(Clause 9, Part 1, Art. 19 of the Code) ${ }^{24}$. However, unambiguous conclusions about belonging of one or another holder of authorities to the subjects of authorities is quite difficult to make from the content of the Code of Administrative Legal Proceedings of Ukraine of 2017 as well, and therefore, one should evaluate the nature of a particular subject based on an analysis of actual disputed legal relations, forms of activity of the subject-defendant, the consequences of exercising their powers for physical persons or legal entities.

Considering an administrative activity as an external manifestation of the subjects of authorities' activities, one can observe, though not fundamental, but certain changes to this criterion in the Code of Administrative Legal Proceedings of Ukraine as revised in 2017. Thus, in addition to the exercise of executive power functions such as conclusion, execution, termination, cancellation of administrative agreements (Art. 4,19 ), it is provided that the activity of the subject of authority may be expressed in the form of administrative service. However, these manifestations of administrative activity are not the only ones. It is worth mentioning that the subjects of authorities take general organizational measures, apply measures of administrative coercion, etc. Therefore, the list of administrative activity forms of the state authorities, stipulated by the Code of Administrative Legal Proceedings of Ukraine in the revision of 2017, remains open and incomplete, and changes in relation to the administrative activity of the subjects of authorities are not fundamental and they do not solve the problem of administrative jurisdiction as a whole.

The Code of Administrative Legal Proceedings of Ukraine of 2017 formulated the definition of normative and legal acts and individual acts for the first time (clause 18, 19 part 1, Art. 4) in addition to such criterion of administrative jurisdiction, as a resolution, action, inaction, an administrative agreement. At the same time, it is known in the practice of functioning of the subject of authorities the following cases when they adopt such acts, which name varies from "normative legal act", "individual act": a resolution, decision, tax notice-decision, protocol, electronic record, etc. So, one can assume that the problem of the nature and type definition for a certain document of the subject of authorities, also complicated by absence of the Code (Law) on Administrative Procedures, will have existed for a certain time.

\footnotetext{
${ }^{24}$ Кодекс адміністративного судочинства України від 6 липня 2005 року № 2747-IV; в редакції Закону України від 3 жовтня 2017 року № 2147-VIII // Відомості Верховної Ради України. - 2017. № $48 .-$ C. 5 .
} 
The administrative law norm, the exercise of rights and observance of obligations in the field of public administration or rights and obligations for violation or non-compliance of which may result in administrative legal consequences are substantive legal criteria, therefore they could not be fundamentally updated or revised in the Code of Administrative Legal Proceedings of Ukraine in the revision of 2017. With the introduction of the Code in a new revised version, these criteria remained unchanged. Therefore, the definition of the nature of law, the type of rights and obligations, essence of public administration will continue to be a problem that has an administrative-legal dimension.

\section{CONCLUSIONS}

It should be stated that having evolved to a certain degree, the Code of Administrative Legal Proceeding of Ukraine as revised 2017 in general, has kept its structure and content. It is supplemented by new institutions (electronic court, settlement of dispute with judge participation) and categories (typical, pattern administrative case), some procedural institutions and categories have been renewed (for example, a judge assistant, expert on law issues is referred to the participants of administrative procedure, the list of disputes belonging to administrative jurisdiction is added).

The content of administrative jurisdiction has been expanded, and now it covers substantive jurisdiction, instance jurisdiction and district jurisdiction (judicature). However, the criteria for determining these types of jurisdiction under the Code of Administrative Legal Proceedings of Ukraine, as revised in 2017, remain essentially unchanged: the object of dispute, the subject (participant) of dispute, court instance, the place of residence (residence, location).

We can see that together with the renewal of the Code of Administrative Legal Proceedings of Ukraine a lot of provisions have appeared requiring additional analysis and justification, that will make administrative legal proceedings more complicated, accordingly, as well as the evaluation of administrative jurisdiction etc.

It is possible to assume that the existing problem of administrative jurisdiction definition and its differentiation from other court jurisdictions will continue to exist.

It can be explained, primarily, by the denial of the existence of complex, multi-branch legal relations; a single and generally accepted understanding of the nature of all possible decisions, actions, inactivity of 
the subjects of authorities, types of such subjects has not been developed. It is believed that the nature of legal relations and the type of court jurisdiction are determined by the legal outcome that occurs as a result of these legal relations.

We hope that overcoming the challenges of definition of court jurisdiction type is a matter of close future, coming closer by developing constant judicial practice by cassation courts, Grand Chamber of the Supreme Court. At the same time, the response about the nature of disputed legal relations as well as determination of administrative jurisdiction criteria has to be formed by the administrative law and procedure science based on the outcomes of administrative proceedings practice.

The following criteria of administrative jurisdiction are offered: 1) administrative-legal relations; 2) the subject of authorities; 3) administrative activity (implementation of administrative powers); 4) the norm of administrative law; 5) the exercise of rights and observance of duties in the field of public administration or rights and obligations, for violations or non-compliance which may result in administrative consequences.

Certainly, in view of the scientific and technological progress achievements, the emergence of new social relations and the adoption of new legislation, these criteria should in no case be taken as final and implicit. They must be constantly reevaluated and tested for suitability with regard to newly emerging social relations.

However, in order for this Code to be used effectively in addressing the problems of administrative jurisdiction, it will be necessary to dedicate a long time to the insistent development of sustainable judicial practice in public-legal disputes, strengthening it by theoretical and applied arguments.

\section{SUMMARY}

Although administrative jurisdiction as an institution of Administrative Procedural Law is envisaged by the Code of Administrative Legal Proceedings of Ukraine and is of great importance not only in the administrative procedures but also in the entire judicial system of Ukraine, it is still not defined in full.

In order to guarantee the full protection of rights, freedoms, interests, the exercise of the right to a fair trial, ensuring the unity of judicial practice, and the stability of the judicial system functioning, the unified 
and generally accepted criteria for the determination of a particular public-legal dispute's belonging to the jurisdiction of the administrative court must be developed.

One should make conclusions about belonging (non-belonging) of certain legal dispute to the administrative court jurisdiction as well as about the possibility of its differentiation from other types of court jurisdiction based on a set of external features of public legal relations that caused such disputes.

Having evaluated the articles of Code of Administrative Legal Proceedings of Ukraine of 2005, it is easy to verify that the law-maker declared in general terms the criteria for the determination of the administrative jurisdiction, the framework and content of the administrative courts' competence. However, such criteria do not allow coming to the single conclusion on the type and nature of a certain public legal dispute.

The content of administrative jurisdiction is supplemented; it contains substantive jurisdiction, instance jurisdiction and territorial jurisdiction (judicature). However, the criteria for the determination of these types of jurisdictions, mainly, remain unchanged - the object of the dispute, the subject (participant) to the dispute, the court instance, the place of residence (location).

It is assumed that the objectively existing problem of the administrative jurisdiction definition and its differentiation from other court jurisdictions will still exist in the future. In our opinion, it can be explained, first of all, by the denial of the existence of complex, multibranch legal relations; a single and generally accepted understanding of the nature of all possible decisions, actions, inactivity of the subjects of authorities, types of such subjects has not been developed. It is believed that the nature of legal relations and the type of court jurisdiction are determined by the legal outcome that occurs as a result of these legal relations.

\section{REFERENCES}

1. Словник іншомовних слів / за ред. О.С. Мельничука. - К.: Головна редакція УРЕ, 1977. - С. 755.

2. Конституція України від 28 червня 1996 року // Відомості Верховної Ради України. - 1996. - № 30. - Ст. 141.

3. Конвенція про захист прав людини і основоположних свобод від 4 листопада 1950 року: ратифікована Законом України від 
17 липня 1997 року № 475/97-ВР // Відомості Верховної Ради України. - 1997. - № 40. - Ст. 263.

4. Бевзенко В.М. Передумови захисту в адміністративному судочинстві прав, свобод, інтересів учасників публічно-правових відносин / В.М. Бевзенко // Сучасна адміністративно-правова доктрина захисту прав людини: тези доп. та наук. повідомл. учасн. наук.-практ. конф. (м. Харків, 17-18 квітня 2015 року). - Харків: Право, 2015. - С. 73-76.

5. Адміністративне судочинство України: теорія та практика: монографія / кол. авт.; за заг. ред. О.М. Нечитайла. - К.: ВАITЕ, 2015. - С. 173-174.

6. Колпаков В.К. Теорія i практика адміністративного судочинства: монографія / В.К. Колпаков, В.В. Гордєєв. - Чернівці: Місто, 2011. - 384 c.

7. Ільков В.В. Правова природа справ адміністративної юрисдикції та іiі вплив на застосування джерел права в адміністративному судочинстві в Україні / В.В. Ільков // Наше право. - 2014. - № 5. - С. 60-70.

8. Куйбіда Р. Межі адміністративної юрисдикції: спірні питання / Р. Куйбіда // Юридичний вісник України. - 2007. № 25(625). - C. 6-7.

9. Адміністративна юстиція України: проблеми теорії i практики. Настільна книга судді / за заг. ред. О.М. Пасенюка. - К.: Істина, 2007. - 608 с.

10. Перепелюк В.Г. Адміністративне судочинство: проблеми практики / В.Г. Перепелюк. - К.: Конус-Ю, 2007. - 272 с.

11. Смокович М.I. Визначення юрисдикції адміністративних судів та розмежування судових юрисдикцій: монографія / М.I. Смокович. - К.: Юрінком Інтер, 2012. - 304 с.

12. Стефанюк В.С. Судовий адміністративний процес: монографія / В.С. Стефанюк. - Харків: Фірма «Консум», 2003. $464 \mathrm{c}$.

13. Цуркан M.I. Правове регулювання публічної служби в Україні. Особливості судового розгляду спорів: монографія / М.I. Цуркан. - Харків: Право, 2010. - 216 с.

14. Про окремі питання юрисдикції адміністративних судів: постанова Пленуму Вищого адміністративного суду України від 20 травня 2013 року № 8 [Електронний ресурс] - Режим доступу: http://zakon0.rada.gov.ua/laws/show/v0008760-13 
15. Про практику застосування адміністративними судами законодавства про доступ до публічної інформації: постанова Пленуму Вищого адміністративного суду України від 29 вересня 2016 року № 10 [Електронний ресурс] - Режим доступу: http://zakon3.rada.gov.ua/laws/show/v0010760-16

16. Про доступ до публічної інформації: Закон України від 13 січня 2011 року № 2939-VI // Відомості Верховної Ради України. 2011. - № 32. - Ст. 314.

17. Кодекс адміністративного судочинства України від 6 липня 2005 року № 2747-IV // Відомості Верховної Ради України. - 2005. № 35-36, № 37. - Ст. 446.

18. Бевзенко В.М. Адміністративна юрисдикція: поняття, сутність, проблеми відмежування / В.М. Бевзенко // Адміністративне право і процес. - 2013. - № 2(4). - С. 180-195.

19. Бевзенко В.М. Новітнє адміністративне процесуальне право України: об'єктивна закономірність чи надумана вигадка? / В.М. Бевзенко // Форум права. - 2011. - № 1. - С. 68-73.

20. Бевзенко В.М. Особливості визначення підвідомчості публічно-правових спорів / В.М. Бевзенко, С.М. Мінько // Вісник господарського судочинства. - 2007. - № 3. - С. 122-126.

21. Кодекс адміністративного судочинства України від 6 липня 2005 року № 2747-IV; в редакції Закону України від 3 жовтня 2017 року № 2147-VIII // Відомості Верховної Ради України. - 2017. - № 48. - C. 5.

\section{Information about the author:} Bevzenko V. M. Doctor of Law, Professor at the Department of Administrative Law, Judge of Administrative Court of Cassation of the Supreme Court of Ukraine 